\title{
Pengembangan Modul IPA Berkarakter Terintegrasi Nilai-Nilai Islam untuk Meningkatkan Sikap Spiritual Peserta Didik SMP/MTs
}

\author{
Muchlis $^{1)}$, Magfirah Perkasa ${ }^{1, *}$ Muhammad Irwansyah $^{1)}$ Ariyansyah $^{1)}$ \\ ${ }^{1)}$ STKIP Bima \\ *magfirahperkasa@gmail.com
}

Abstrak: Pendidikan nasional bertujuan untuk menghasilkan peserta didik yang memiliki kecerdasan yang utuh baik itu kecerdasan intelektual, kecerdasan emosional, kecerdasan spiritual maupun kecerdasan sosial. Namun fakta dilapangan berkata lain. Kecerdasan spiritual dan sosial cenderung dikesampingkan oleh pendidik di sekolah. Oleh karena itu dilakukannya penelitian ini dengan tujuan menghasilkan modul IPA berkarakter terintegrasi nilai-nilai Islam untuk meningkatkan sikap spiritual siswa atau yang memenuhi kriteria valid dan efektiv. Jenis penelitian yaitu penelitian pengembangan yang mengikuti tahapan pengembangan Thiagarajan yang terdiri dari tahap pendefinisian (define), perancangan (design), pengembangan (develop) dan penyebaran (disseminate). Adapun instrumen yang digunakan yaitu lembar validasi, dan angket respon siswa. Hasil penelitian menunjukkan bahwa modul IPA yang dikembangkan memenuhi kategori kevalidan dengan nilai $M=3,23$. Sedangkan angket respon siswa ada dalam kategori positif sebesar $66,67 \%$ dan sangat positif sebesar $33,33 \%$. Dengan demikian dapat disimpulkan bahwa modul IPA berkarakter terintergasi nilai-nilai Islam memenuhi kriteria valid dan efektif untuk diterapkan pada siswa SMP/MTs.

Kata Kunci: Modul IPA, Berkarakter Islam

\section{Pendahuluan}

Pendidikan nasional bertujuan untuk menghasilkan peserta didik yang memiliki kecerdasan yang utuh baik itu kecerdasan intelektual, kecerdasan emosional, kecerdasan spiritual maupun kecerdasan sosial. Namun fakta dilapangan berkata lain bahwa para alumni yang berpendidikan bahkan yang sementara menempuh pendidikan mempraktekan perbuatan-perbuatan yang tidak mencirikan sebagai seseorang yang berpendidikan. Misalnya praktek korupsi, kolusi dan nepotisme (KKN) dikalangan pejabat, tawuran antara pelajar, narkoba dan penyebaran minuman keras marak terjadi dikalangan remaja Indonesia (Abidin, 2012; Irwansyah \& Ariyansyah, 2019). Data KPK 2020 ada 300 kepala daerah terlibat kasus korupsi, Data BNN 2019 pengguna narkoba di Indonesia mencapai 4,5 Juta orang. Survey komnas perlindungan anak 2010 kepada remaja usia SMP dan SMA di 12 Provinsi hasilnya: terdapat $97 \%$ siswa pernah melihat film porno, 93,7\% pernah berciuman, 62,7\% pernah aborsi (Salafudin, 2019). Permasalahan tersebut menjadi tantangan bagi para tenaga pendidikan untuk menghasilkan peserta didik yang memiliki kompetensi sempurna. Dimana tenaga pendidikan dalam proses pengajaran tidak hanya fokus pada pencapaian kecerdasan kognitif namun harus memperhatikan juga kecerdasan spiritual dan sikap peserta didik. Jika permasalahan degradasi moral remaja Indonesia terus dibiarkan tanpa solusi maka bukan mustahil potret pelajar dan remaja Indonesia semakin buram (Mujahidin, 2005).

Menyikapi permasalahan yang dihadapi oleh peserta didik Kementerian pendidikan dan kebudayaan mengembangkan kurikulum 2013. Kurikulum 2013 menempatkan sikap spiritual pada urutan pertama dari kompetensi inti dan sikap sosial pada urutan kedua. Hal ini dapat dimaknai bahwa kurikulum 2013 sangat memberi penekanan pada pengembangan karakter dan kepribadian peserta didik. Kurikukulum 2013 juga mengangkat tentang adanya keseimbangan antara keterampilan, pengetahuan dan sikap untuk membangun hard skill dan soft skill peserta didik (Okmarisa, 2016; Hasanah, 2018). Maka setiap pendidik di sekolah harus mengarahkan belajar peserta didik kearah belajar untuk beriman dan bertaqwa kepada Tuhan yang maha esa. Hal ini menggaris bawahi perlunya pengintegrasian antara imtaq dengan iptek. Salah satu pendekatan yang menawarkan hal tersebut adalah pendekatan integratif. Pendekatan integratif merupakan usaha untuk 
menjadikan lulusan pendidikan tahu tentang sains bahkan menyukai sains dan teknologi, perkembangan serta implikasinya terhadap lingkungan, masyarakat, peningkatan keimanan dan ketaqwaan (Irwansyah, Nurfathurrahmah \& Arifin, 2018).

Guru mata pelajaran umum dapat mengintegrasikan antara sains dengan agama melalui materi pelajaran, proses pembelajaran, bahan ajar dan media pembelajaran. Pembelajaran sains harus digunakan sebagai alat untuk menjamin pertumbuhan keimanan dan ketaqwaan siswa kepada tuhan yang maha esa. Menghadirkan aspek spiritual agama dalam sains tidak akan mengurangi kadar ilmiahnya melainkan akan saling mengisi dan menguatkan yang akan menjadi sarana tercapainnya keimanan dan taqwa (Wildan, 2008; Darmana, 2013). Pengembangan modul dan lembar kerja peserta didik berorientasi nilai-nilai agama Islam valid untuk digunakan dalam kegiatan pembelajaran (Latifah, 2016; Rakhmatullah, Rapi \& Zulkarnaim, 2020). Penerapan bahan ajar fisika diintegrasikan dengan nilai-nilai alquran dapat meningkatkan hasil belajar peserta didik pada aspek kognitif, aspek sikap spiritual berupa iman, syukur, dan menghayati kebesaran dan kekuasaan Allah SWT serta dapat meningkatkan aspek sikap sosial berupa jujur, disiplin, kerjasama, rasa ingin tahu dan tanggung jawab (Niimati \& Mursalin, 2018).

Oleh karena itu dilakukannya penelitian ini. Penelitian ini bertujuan untuk mengembangkan modul IPA berkarakter terintegrasi nilai-nilai islam yang memenuhi kriteria valid dan efektiv. Penelitian ini penting untuk dilakukan karna modul IPA berkarakter yang diintegrasikan dengan nilai-nilai islam selain dapat meningkatkan pengetahuan sains peserta didik, juga dapat meningktakan kompetensi sikap spiritual peserta didik. Dari hasil penelitian ini modul IPA berkarakter dapat dijadikan sebagai acuan untuk perbaikan kualitas pendidikan di kota Bima dan kabupaten Bima provinsi NTB.

\section{Metode}

Penelitian ini adalah penelitian pengembangan (Reseach and Development) dengan mengadopsi model pengembangan Thiangarajan. Dalam penelitian ini ada 4 langkah-langkah atau tahapan- tahapan yang akan dilakukan yaitu tahap pendefenisian (define), tahap perancangan (design), tahap pengembangan (develop) dan tahap penyebaran (disseminate). Adapun instrumen yang digunakan untuk mengukur kualitas modul IPA berkarakter yaitu lembar validasi dan angket respon siswa. Modul IPA berkarakter hasil pengembangan di ujicobakan pada siswa kelas VIII MTsN 1 kota Bima tahun pelajaran 2020/2021. Setelah itu data dianalisis dengan menggunakan metode analisis statistik deskriptif.

\section{Hasil dan Pembahasan}

\section{Tahap pendefinisian}

Hasil dari tahap pendefinisian didapatkan modul IPA yang digunakan guru adalah modul yang dibeli dipasaran dan didownload dari internet. Isi dari modul IPA tersebut hanyalah sebatas materi tanpa diintegrasikan dengan pendidikan karakter dan pendekatan integratif. Padahal kurikulum 2013 mengamanahkan agar terjadi peningkatan disegala kompetensi baik itu kompetensi pedagogik, kompetensi pengetahuan, dan kompetensi sikap sosial dan sikap spiritual siswa. Jadi guru dalam proses belajar mengajar harus berusaha menghadirkan kegiatan pembelajaran yang dapat merangsang terjadinya peningkatan sikap spiritual siswa. Pembelajaran yang bermuatan nilai ketuhanan memiliki peranan penting dalam menyiapkan generasi yang lebih berkualitas, yang menguasai ilmu pengetahuan dan teknologi dengan akhlak yang baik (Sundari, Heliawati, \& Permanasari. 2020).

\section{Tahap perancangan}

Modul pembelajaran yang dikembangkan disesuaikan dengan kebutuhan siswa MTsN 1 kota Bima provinsi NTB. Didalam modul pembelajaran terdapat penguatan pendidikan karakter dan nilai-nilai keislaman atau pendekatan integratif sebagai solusi dari berbagai kasus yang dilakukan oleh pelajar kota Bima provinsi NTB. Modul tersebut diharapkan memberikan kesempatan kepada siswa untuk mengkonstruksi sendiri pemikirannya sehingga mempengaruhi sikap siswa. Hal ini didukung oleh pernyataan Hanif, Ibrohim \& Rohman, 2016 bahwa integrasi nilai agama kedalam mata pelajaran sains bertujuan membangun karakter siswa yang tidak hanya cerdas secara kognitif namun juga cerdas secara sikap dan perilakunya. Didukung juga oleh 
pernyataan Jamilah at.al., 2014; Sosilowati, 2017 bahwa integrasi nilai agama dalam pembelajaran sains berpotensi menghasilkan manusia yang baik dan religius.

\section{Tahap pengembangan}

Pada tahap ini dilakukan validasi oleh 2 orang validator ahli yaitu ahli materi dan ahli media pembelajaran. Adapun hasil validasi modul IPA berkarakter terintegrasi nilai-nilai Islam dapat dilihat pada tabel 1.

Tabel 1. Hasil validasi modul IPA

\begin{tabular}{|c|c|c|c|}
\hline No. & Aspek pengamatan & $\bar{x}$ & Keterangan \\
\hline 1 & Kontruksi isi & 3,14 & Valid \\
\hline 2 & Tampilan & 3,31 & Valid \\
\hline 3 & Kelengkapan materi & 3,67 & Sangat Valid \\
\hline 4 & Kesesuaian dengan kompenen lain (RPP dan LKS) & 3,00 & Valid \\
\hline 5 & Tata Bahasa & 3,10 & Valid \\
\hline \multirow[t]{2}{*}{6} & Manfaat & 3,16 & Valid \\
\hline & Rerata total & 3,23 & Valid \\
\hline
\end{tabular}

Berdasarkan hasil penilaian 2 orang validator ahli, diperoleh hasil bahwa secara keseluruhan modul IPA berkarakter terintegrasi nilai-nilai Islam secara umum dinyatakan valid dengan nilai rerata total $M=3,23$. Namun walaupun modul pembelajaran IPA memenuhi kriteria kevalidan terdapat beberapa saran dari validator diantaranya penguatan pendidikan karakter sebaiknya ditambahkan nilai gotong royong dan kerjasama, kejelasan warna gambar, kejelasan penulisan ayat alquran dan hadis nabi, serta soal dalam modul disesuaikan dengan kondisi siswa usia SMP/MTs. Menurut Arsyad (2013) media pembelajaran yang dibuat harus disesuaikan dengan kebutuhan atau psikologis siswa dan konteks kehidupan nyata agar proses pembelajaran dapat terlaksana secara efektiv. Apabila materi atau soal disesuaikan dengan kehidupan nyata maka siswa akan terbiasa memberikan sumbangan pemikiran dan solusi terhadap berbagai permasalahan yang ada dimasyarakat (Imaduddin \& khafidin 2018).

Setelah dilakukan validasi kemudian modul IPA hasil pengembangan diujicobakan secara terbatas dengan tujuan untuk mengetahui respon peserta didik terhadap modul IPA berkarakter terintegrasi nilai-nilai Islam. Ujicoba terbatas dilakukan secara online dengan cara membagi angket respon siswa kepada peserta didik MTsN 1 Bima provinsi NTB pada kelas VIII. Pelaksanaannya dimulai pada bulan Juli 2020. Adapun data hasil pembagian angket respon siswa terhadap modul IPA berkarakter dapat dilihat pada tabel 2 .

Tabel 2: Angket respon siswa

\begin{tabular}{ccc}
\hline No & Uraian & Keterangan \\
\hline 1 & Sangat Positif & $33,33 \%$ \\
2 & Positif & $66,67 \%$ \\
3 & Negatif & $0 \%$ \\
\hline
\end{tabular}

Setelah dilakukan analisis data, respon siswa pada modul IPA berkarakter terintegrasi nilai-nilai Islam hasl pengembangan berada pada kategori positif dan sangat positif. Terdapat $66,67 \%$ siswa yang memberikan respon positif dan terdapat $33,33 \%$ siswa yang memberikan respon sangat positif. Sedangkan siswa yang memberikan respon negatif $0 \%$. Data tersebut menunjukkan bahwa modul IPA berkarakter hasil pengembangan sesuai dengan kebutuhan siswa. Dimana dalam konteks pembelajaran abad 21 siswa tidak hanya bertindak sebagai pencari ilmu namun mereka harus mampu berpikir kritis, berpikir kreatif dan memberikan solusi terhadap berbagai permaslahan yang terjadi dimasyarakat dengan tidak melanggar aturan dan norma yang berlaku disuatu daerah.

\section{Simpulan}

Setelah dilakukanya penelitian tentang pengembangan modul IPA berkarakter terintegrasi nilai-nilai Islam maka dapat ditarik kesimpulan bahwa modul IPA berkarakter memenuhi kriteria kevalidan dengan nilai M= 3,23. Sedangkan hasil ujicoba terbatas dengan melihat respon siswa terhadap modul IPA berkarakter terintegrasi 
nilai-nilai Islam berada pada kategori positif dan sangat positif. Jadi modul IPA berkarakter terintegrasi nilai-nilai Islam memenuhi kriteria valid dan efektiv untuk diterapkan pada peserta didik SMP/MTs.

\section{Ucapan Terima Kasih}

Ucapan terima kasih penulis sampaikan kepada Direktorat Riset dan Pengabdian Masyarakat-Kemenristek dan Pimpinan STKIP Bima yang telah membantu mendanai dan memberikan ijin untuk melakukan penelitian ditahun 2020 melalui Hibah Penelitian Dosen Pemula (PDP).

\section{Daftar Pustaka}

Abidin, Y. (2012). Model Penilaian Otentik dalam Pembelajaran Membaca Pemahaman Berorientasi Pendidikan $\begin{array}{lllll}\text { Karakter. Jurnal } & \text { Pendidikan } & \text { Karakter, } & \text { 2(2), }\end{array}$ https://journal.uny.ac.id/index.php/jpka/article/view/1301.

Arsyad, A. 2013. Media Pembelajaran (Edisi Revisi Cetakan ke-16). Jakarta: PT. Raja Grafindo Persada.

Darmana, A. et.all. 2013. Pandangan Siswa Terhadap Internalisasi Nilai Tauhid Melalui Materi Termokimia. Prosiding Semirata. FMIPA UNILA Lampung. https://jurnal.fmipa.unila.ac.id/semirata/article/view/788.

Hanif., Ibrohim \& Rohman F. 2016. Pengembangan Perangkat Pembelajaran Biologi Materi Plantae Berbasis Inkuiri Terbimbing Terintegrasi Nilai Islam untuk Meningkatkan Pemahaman Konsep Siswa SMA. Jurnal Pendidikan: Teori, Penelitian dan Pengembangan, 2165. http://journal.um.ac.id/index.php/jptpp/article/view/8042/3665.

Hasanah, N., \& Zuhaida, A. 2018. Desain Madrasah Sains Integratif: Integrasi Sains Agama dalam Pelaksanaan dan Perangkat Pembelajaran. Edukasia: Jurnal Penelitian Pendidikan Islam, 13 (1), $164 .$. https://journal.iainkudus.ac.id/index.php/Edukasia/article/view/3517.

Jamilah. et.all. 2014. Integration of Islamic Input in Medical Curriculum - Universiti Sains Islam Malaysia (USIM). The International Medical Journal of Malaysia, 13 (2), 76. https://www.researchgate.net/publication/292426796_Integration_of_Islamic_input_in_medical_cur riculum_-_Universiti_Sains_Islam_Malaysia_USIM_experience.

Imaduddin, M., \& khafidin, Z. 2018. Ayo Belajar IPA dari Ulama: Pembelajaran Berbasis Socio-Scientific Issues $\begin{array}{llllll}\text { di } & \text { Abad } 21 . & \text { Jurnal } & \text { Thabiea, } & 1(2), & \end{array}$ https://journal.iainkudus.ac.id/index.php/Thabiea/article/view/4439.

Irwansyah, M., Nurfathurrahmah., \& Arifin. 2018. Pengembangan Perangkat Pembelajaran IPA Terpadu Berorientasi Model PBL dengan Pendekatan Integratif untuk Meningkatkan Kompetensi Sikap dan $\begin{array}{lllll}\text { Pengetahuan Siswa. Oryza: Jurnal Pendidikan Biologi, } & 1(2), & 30 .\end{array}$ http://jurnal.stkipbima.ac.id/index.php/OZ/article/view/4.

Irwansyah dan Ariyansyah. 2019. Perangkat pembelajaran berorientasi pendidikan karakter Untuk meningkatkan sikap dan pengetahuan siswa. Lentera Pendidikan: Jurnal Ilmu Tarbiyah dan Pendidikan, 22 (1), 1-2. http://journal.uin-alauddin.ac.id/index.php/lentera_pendidikan/article/view/6656.

Latifah, S. et. All. 2016. Pengembangan Lembar Kerja Peserta Didik (LKPD) Berorientasi Nilai-Nilai Agama Islam Melalui pendekatan Inkuiri Terbimbing pada Materi Suhu dan Kalor. Jurnal Ilmiah Pendidikan AlBiruni, 5 (1), 50. http://ejournal.radenintan.ac.id/index.php/al-biruni/article/view/104/0.

Mujahidin, E. 2005. Pesantren Kilat Alternatif Pendidikan Agama di Luar Sekolah. Jakarta Timur: Pustaka AlKautsar.

Niimati, RA dan Mursalin. Penerapan Bahan Ajar Fisika Berbasis Nilai-Nilai Al-Qur'an pada Konsep Gerak Melingkar untuk Meningkatkan Hasil Belajar Siswa Kelas X Madrasah Aliyah. Prosiding Seminar Nasional Quantum. Pendidikan Fisika UAD. http://seminar.uad.ac.id/index.php/quantum/article/view/250.

Okmarisa, H. et.all. 2016. Implementasi Bahan Ajar Kimia Terintegrasi Nilai Spiritual dengan Model Pembelajaran Problem Based Learning (PBL) Berorientasi Kolaboratif untuk Meningkatkan Hasil Belajar 
$\begin{array}{lllll}\text { Siswa. Jurnal } & \text { Pendidikan } & \text { Kimia, } & \text { 8(2), }\end{array}$ https://jurnal.unimed.ac.id/2012/index.php/jpk/article/view/4439.

Rakhmatullah., Rapi M., \& Zulkarnaim. 2020. Pengembangan Modul Pembelajaran Biologi Materi Sistem Reproduksi Terintegrasi Keilmuan Islam untuk Siswa Kelas XI Madrasah Aliyah. Jurnal Biotek, 8(1), 6768. http://journal.uin-alauddin.ac.id/index.php/biotek/article/view/9287.

Salafudin. 2019. Penanaman Nilai-Nilai Pendidikan Islam melalui Pembelajaran Matematika. HIKMATUNA: Journal For Integrative Islamic Studies, 5 (1), 30. journal.iainpekalongan.ac.id/index.php/hikmatuna/article/view/1860.

Sosilowati, S. 2017. Pengembangan Bahan Ajar IPA Terintegrasi Nilai Islam untuk Meningkatkan Hasil Belajar IPA. Jurnal Inovasi Pendidikan IPA, 3 (1). https://journal.uny.ac.id/index.php/jipi/article/view/13677

Sundari, U., Heliawati, L., \& Permanasari, A. 2020. Students' Perception of The Internalization Of Islamic Values in Buffer Solution Teaching Materials. JIPI (Jurnal IPA dan Pembelajaran IPA), 4(2), 133. http://jurnal.unsyiah.ac.id/JIPI/article/view/16730.

Wildan, H. 2008. Pengembangan Pembelajaran Sains Berorientasi Iman dan Taqwa. Jurnal Pijar MIPA, 3(1), 31. http://jurnalfkip.unram.ac.id/index.php/JPM/article/view/180. 